\title{
REGBININKŲ SAVĘS VERTINIMO IR AGRESYVUMO FORMŲ SĄSAJOS
}

\author{
Loreta Zajančkauskaitè-Staskevičienė, Asta Milerytė \\ Vytauto Didžiojo universitetas, Kaunas, Lietuva
}

\begin{abstract}
Loreta Zajančkauskaitè-Staskevičienè. Socialinių mokslų daktarè. Vytauto Didžiojo universiteto Socialinių mokslų fakulteto Psichologijos
\end{abstract} klinikos jaunesnioji mokslo darbuotoja. Moksliniu tyrimų kryptis — socialinè ir sveikatos psichologija.

\section{SANTRAUKA}

Smurtas sporto srityje, pasireiškiantis per sportinę kova ir ne tik jos metu, tampa rimta socialine problema. Daugelis autoriu ieško priežasčiu, lemiančiu agresyvu elgesį. Analizuojami situaciniai veiksniai, asmeninès savybès, kontekstas. Agresyvios reakcijos, gebejjimas tokius impulsus kontroliuoti ar ju energija iškrauti socialiai priimtinu būdu glaudžiai siejasi su savęs vertinimu. Savęs vertinimo tyrimai sportinès veiklos požiūriu nèra gausūs, todèl šio tyrimo objektu pasirinkome kontaktinès šakos sportininku savęs vertinima ir agresyvumo ypatumus. Pagal sužalojimu statistika regbis priskiriamas agresyviausioms sporto šakoms, todèl tikejjomès, kad regbininku agresyvumo formos bus aiškiai išreikštos. Šio tyrimo tikslas — nustatyti regbininku savęs vertinimo ir agresyvumo formu sqsajas.

Buvo tiriami 104 regbininkai vyrai, besitreniruojantys jauniu ir suaugusiuju komandose. Tiriamuju amžius 16-32 m., amžiaus vidurkis 20,75 m. Tyrimo metu naudota M. Rosenberg (1986) savęs vertinimo skale ir Buss-Durkee (1957) agresyvumo klausimynas. Statistinei duomenu analizei atlikti naudota SPSS programa (10.1 versija).

Rezultatai parodè, kad tirtiems regbininkams büdingiausios verbalinès ir fizinès agresijos formos, t. y. aktyvus, atviras agresijos išreiškimas, o mažiausiai būdinga netiesioginè agresija ir negatyvizmas, t. y. „,atsargesnis “, pasyvesnis agresijos išreiškimas.

Analizuodami duomenis pagal amžiu nustatème, kad ịtarumas ir kaltès jausmas büdingesni jaunesniems regbininkams - jaunesni regbininkai labiau nepasitiki aplinkiniais ir projektuoja savo priešiškuma i kitus. Negatyvizmas büdingesnis vyresniems tiriamiesiems. Galima manyti, kad vyresni regbininkai labiau drista nepritarti kitu sugalvotoms taisyklems ar garbingos kovos principams.

Vyresniu regbininku grupejje (aukštesnio savęs vertinimo) savęs vertinimo ir suminio agresyvumo rodiklio sq̨aju neaptikta, tačiau jaunesniu regbininku grupejje nustatytas neigiamas ryšys: kuo žemesnis savęs vertinimas, tuo aukštesnis agresyvumo ¿̇vertis. Tokie rezultatai atitinka daugumos tyrèju išvadas, kad bütent žemas savęs vertinimas yra agresyvumo rizikos veiksnys. Vyresniu regbininku savęs vertinimas patikimai siejosi tik su verbaline agresija: kuo aukštesnis savęs vertinimas, tuo labiau išreikštas polinkis verbalinei agresijai. Priešiškumas, susierzinimas, nuoskauda ir negatyvizmas neigiamai koreliuoja su jaunesniu regbininku savęs vertinimu.

Raktažodžiai: agresyvumas, instrumentine agresija, savęs vertinimas.

\section{IVADAS}

$\mathrm{S}$ murtas sporto srityje, pasireiškiantis per sportinę kovą ir ne tik jos metu, tampa rimta socialine problema. Daugelis autorių ieško atsakymu, kas lemia netoleruojamo agresyvaus elgesio poreiškius. Analizuojami situaciniai veiksniai, asmeninès savybès, kontekstas. Nuolatinis varžymasis sporto šakos rungtynèse, ypač tokiu kaip futbolas, krepšinis, regbis, reikalauja agre- syvios žaidimo taktikos, bet neatsiejamas ir nuo veiksnių už aikštelès ribų.

Dažniausiai tiriamos agresijos apraiškos tarp žaidèjų, sirgalių, trenerių. Analizuojami įvairūs agresiją sporto srityje skatinantys veiksniai: motyvacija laimèti, genai, lytis, charakterio bruožai ir pan. Rungtyniavimas savo prigimtimi numato agresyvius impulsus, tačiau tai, ar kova peržengs 
taisykliu numatytas ribas, priklauso nuo daugelio veiksnių. Savęs vertinimas yra viena iš asmenybès savybių, kuri daro didelę ittaką žmogaus visavertiškumui, tarpasmeniniam bendravimui, poreikiui varžytis su kitais ir pan. Savęs vertinimo tyrimai sportinès veiklos požiūriu nèra gausūs, todèl šio tyrimo objektu pasirinkome kontaktinès šakos sportininkų savęs vertinimą ir agresyvumo ypatumus.

Anot L. A. Kirkpatrick ir kt. (2002), vienas iš svarbesnių kintamujų, tiriant agresijos reiškini, yra savęs vertinimas. Nuo jo priklauso žmogaus santykiai su aplinkiniais, požiūris į savo laimejjimus ir nesėkmes. Ivertinant save svarbu, kiek patiriama pagarbos, kaip vertina kiti, ar patiriama sèkmè. Kaip teigia S. Heimpel ir kt. (2002), žemo savęs vertinimo asmenys labiau paveikiami neigiamu ìvykių, dažniau patiria susirūpinimą ir disforiją, negu aukšto savęs vertinimo. Agresyvios reakcijos, gebejjimas agresyvius impulsus kontroliuoti ar jų energiją iškrauti socialiai priimtinu būdu taip pat susijęs su savęs vertinimu ( Hubbard, 2006).

Neadekvatus aukštas savęs vertinimas gali sukelti ir agresiją, kuri pasireiškia noru dominuoti ir būti padèties šeimininku bet kurioje situacijoje (Valickas, 1997). Priešiškumas gali kilti, kai pajaučiama grèsmè teigiamam savęs vertinimui (Perez et. al., 2005). Visgi kyla klausimas, kodèl vieni aukšto savęs vertinimo žmonès linkę i agresija, kiti (tokio paties savęs vertinimo) - nelinkę. Viena iš nuomonių: žmonès, save vertinantys aukštai, bet nestabiliai, labiausiai linkę i priešiškumą ir pykti, o aukšto, bet stabilaus savęs vertinimo - mažiausiai linkę i agresiją (Bushman, Baumeister, 1998).

Agresiją gali skatinti gedos jausmas, siejamas su numanomu arba realiu kitų žmonių nepalankiu vertinimu. I tokią teigiamo savęs vertinimo grèsmę žmogus linkęs reaguoti pykčiu, noru nubausti kitus, ịtarumu, kitų kaltinimu dèl neigiamų ivvykių (Tangney et al., 1992). Pyktis, nukreiptas prieš gèdą sukèlusius objektus, veikia kaip gynybos mechanizmas, kad būtų apsaugotas teigiamas savęs vertinimas.

Agresyvus elgesys, kaip ir kitos elgesio formos, yra prigimties bei patirties sąveikos rezultatas. Pagal biologinę teoriją agresyvumas individui yra igimtas, taip reiškiasi instinktyvi prigimtis. Šios teorijos pradininkai aiškino, kad žmonès savo pykti gali paversti sportiniu, todèl sportas gali būti naudingas, o agresijos proveržis sporto aikštelèje gali apsaugoti nuo pykčio proveržio visuomenèje. Visgi ši nuomonè yra ginčytina, nes dar nėra visiškai aišku, ar sportas mažina agresyvumą, ar, priešingai, gali sustiprinti agresyvų elgesị.

Išmokimu pagristos agresijos teorijos teigia, kad agresyviai reaguoti išmokstama. Pastiprinimu laikomas apdovanojimas už agresyvius veiksmus: jei pasiekiamas rezultatas (pvz., jei pavyko varžovą ibauginti arba jis pasidavè), tai agresyvūs veiksmai naudojami ir toliau. Sportininkui pastiprinimą gali suteikti ir žiūrovų pritarimas, ir varžovo pasitraukimas iš konfliktinès situacijos (Malinauskas, 2003).

Skiriamos dvi agresijos rūšys: pykčio agresija, skatinama savisaugos, ir instrumentine agresija, skirta tikslams pasiekti. Instrumentinè agresija dar skirstoma i fizinę ir verbalinę, aktyvią ir pasyvią, tiesioginę ir netiesioginę. Fizinès agresijos išraiška yra skausmo sukèlimas kitam. Žodinè agresija - tai reakcija, kuria atstumiama arba grasinama. Tiesioginè agresija nukreipta i šalia esantị tos agresijos tikslą arba auką, o netiesioginé gali pasireikšti kenkimu per atstumą. Aktyvi agresija pasireiškia instrumentiniais veiksmais, kurie perduoda nemalonų impulsą, pasyvi - neveikimu arba veiksmais, neleidžiančiais aukai pasiekti norimų tikslų (Žukauskienè, 2006).

Sporto srityje dažniausiai reiškiasi instrumentinè agresija, t. y. agresija naudojama pergalei pasiekti. Skirtumai tarp lyčiu agresyvaus elgesio požiūriu yra daugiau kokybinio nei kiekybinio pobūdžio (Ruibytè, 2004). Vyrai ir moterys panašiai naudoja fizinę ir žodinę agresiją sporto srityje, o svaigiuju gèrimų vartojimas padidina moteru žodinę agresiją (Storch, et. al, 2005).

Mokslinèje literatūroje diskutuojama, koks sporto poveikis asmenybès socialiniam prisitaikymui ir saviugdai. Vieni autoriai teigia, kad sportavimas gali skatinti psichosocialini asmenybès vystymąsi: didinti savigarba, pasitikejjimą savo gebejimais, emocini pastovumą ir pan. Kita nuomoné teigia, kad sportinè veikla gali ugdyti ir neigiamus asmenybės bruožus: dominavimą, priešiškumą, savanaudiškumą, grubumą, nepaklusnumą taisyklèms, nedrausmingumą (Šniras ir kt., 2007).

Su sportu susijęs smurtas pastebimas visuose sporto lygmenyse, nuo vaiku iki profesionalių suaugusiujuc lygų (Fields, et. al, 2007). T. Stornes ir E. Roland (2004) atkreipé dèmesi i agresyvią laimejjimų strategiją. Jie apibrèžè instrumentinę agresiją kaip specifinę sporto strategiją, kuri nukreipta i apdovanojima, t. y. laimèjima. Tyrimo rezultatai parode, kad paaugliai, turintys valdžios siekimo poreiki, be pergalès siekio gali siekti socialinio dominavimo, rodyti mažiau pagarbos priešininkams, 
naudotis neteisètomis priemonėmis. A. Dumčienė ir kt. (2008) nagrinejjo mokinių sportavimo sąsajas su psichosocialine sveikata. Jie taip pat nustate, kad fizinè agresija būdingesnè aktyviai sportuojantiems mokiniams. Aiškinama, kad sportavimas susijęs su siekimu dominuoti prieš kitus per fizinę jègą, ir sportinè veikla ne visada gali apsaugoti nuo issitraukimo ił agresyvų elgesị.

I. M. Endresen ir D. Olweus (2005) akcentuoja asmenybės bruožų poveikị agresyvumo raiškai sporto srityje ir tvirtina, kad agresyvumo išraiškos sportuojant atitinka agresyvumą kasdienejje aplinkoje. Anksčiau buvo manoma atvirkščiai, kad jègos sportas sumažina agresyvaus elgesio apraiškas. Tyrejjai analizavo žurnalistinius pranešimus apie sportininkų agresiją ir padare išvada, kad kontaktinio sporto šaku (bokso, ledo ritulio, futbolo ir kt.) žaidèjai labiau išreiškia agresiją ir kasdieniame gyvenime (Endresen, Olweus, 2005). Remdamiesi savo tyrimo rezultatais, autoriai pastebi désningumą: jei paauglys turi polinki $i$ agresija, tai jis rinksis didesnès jègos ir varžymosi reikalaujančią sporto šaką, o jègos sportas (boksas, imtynès, sunkioji atletika, kovos menai ir kt.) siejasi su destruktyviu elgesiu už sporto salès ribų. Neaptikta ịrodymų, kad jëgos sportas galètu sumažinti paaugliu agresiją kasdieniame gyvenime (Endresen, Olweus, 2005).

Manoma, kad sportas yra socialinė aplinka, kuri suteikia galimybę bendraamžių sąveikai, suteikia sąlygas socialinio palaikymo, savigarbos augimui. Tyrimai rodo, kad paaugliai ir suaugę sportininkai yra aukštesnès savigarbos negu nesportininkai. Drovūs vaikai, dalyvaujantys sportinejje veikloje, yra aukštesnès savigarbos negu nesportuojantys drovūs jų bendraamžiai. Sportuojantys agresyvūs vaikai yra aukštesnès savigarbos negu agresyvūs nesportuojantys (Findlay, Coplan, 2008). Galima manyti, kad sportuojantys vaikai jaučiasi vertingesni ir kompetentingesni jų socialinèje grupejje, todèl didejja ir jų savigarba. Tai ypač aktualu prisitaikymo sunkumu turintiems vaikams.

D. Šertvytienè ir S. Laskienè (2008) atkreipia dèmesi i sportuojančių paauglių socialinès kompetencijos jausma, kuris susijęs su savęs vertinimu. Tyrimas parode, kad sportuojantys vaikinai labiau negu nesportuojantys pasitiki savimi, geba reikšti tiek teigiamus, tiek neigiamus jausmus, labiau geba kontaktuoti su pažistamais ir nepažistamais žmonėmis. Teigiamą fizinio aktyvumo poveiki asmenybès socialinei integracijai akcentuoja ir kiti autoriai (Vainiené, Kardelis, 2008).
Taigi agresyvumo sporto srityje reiškinys tiriamas įvairiais aspektais, tyrimų duomenys dažnai prieštaringi. Nèra aišku, ar agresyvesnieji renkasi agresyvesnę sporto šaką, ar dèl leistinų agresyvaus žaidimo taisyklių sportuojantieji gali tapti agresyvesni. Pagal sužalojimų statistiką regbis priskiriamas agresyviausioms sporto šakoms (Brandenburg et al., 2007), todèl tiketina, kad regbininku agresyvumo ypatumai bus aiškiai išreikšti. Šio tyrimo tikslas - nustatyti regbininkų savęs vertinimo ir agresyvumo formų sąsajas. Tikrinama hipotezė: aukštesnis regbininkų savęs vertinimas susijęs su aktyviomis agresyvumo formomis (fizine ir verbaline agresija), žemesnis savęs vertinimas - su pasyviomis agresyvumo formomis (susierzinimu, negatyvizmu ir pan.).

\section{TYRIMO METODIKA}

Tiriamieji. Buvo tiriami 104 regbininkai vyrai, besitreniruojantys jaunių ir suaugusiujų komandose. Komandu sportiniai laimėjimai gana ivairūs, tačiau meistriškumo lygis panašus (rinktinès nariai nebuvo tiriami). Jaunių komandas sudare jaunuoliai nuo 16 iki 18 metu, suaugusiuju — nuo 19 metų ir vyresni. Tiriamujų amžius $16-32 \mathrm{~m}$., amžiaus vidurkis $20,75 \mathrm{~m}$., standartinis nuokrypis 4,70 . Nè vienas klausimynas nebuvo atmestas kaip sugadintas.

Metodika. Tyrimo metu naudota M. Rosenberg (1986) savęs vertinimo skalè (laisvai prieinama internetu: http://www.bsos.umd.edu/socy/ Research/rosenberg.htm). Klausimyną sudaro 10 teiginių, kurie parodo, kiek žmogus jaučiasi kompetentingas tenkinti savo poreikius, yra palyginti pastovus ivairiose situacijose.

Tiriamasis turi iqvertinti kiekvieną teigini nuo 1 iki 4 balų. Kuo didesne iqvertinimų suma, tuo ji rodo aukštesnį asmenybės savęs vertinimą. Lietuviškos skalès versijos vidinio patikimumo rodiklis Kronbacho alfa (Cronbach $\alpha$ ) 0,647.

Taip pat naudotas Buss-Durkee (1957) agresyvumo klausimynas (Ратанова, Шляхта, 2008). Klausimyną sudaro 75 teiginiai, kurie atskleidžia žmogui būdingas agresyvumo rūšis. Tiriamasis turi ịvertinti kiekvieną teiginį balais: 0 - būdinga arba 1 - nebūdinga. Atliktas dvigubas klausimyno vertimas, lietuviškos skalès versijos subskaliu vidinio patikimumo rodiklis Kronbacho alfa tinkamas grupiu vertinimui: nuo 0,500 (nuoskaudos subskalès) iki 0,716 (fizinès agresijos subskalès). Statistinei duomenu analizei atlikti naudota SPSS programa (10.1 versija). 


\section{REZULTATAI}

Norint palyginti regbininkų savęs vertinimą pagal amžių remtasi sukauptuoju dažniu (50\%) ir išskirtos dvi amžiaus grupès po 51 tiriamaji: jaunesniu (16-18 m.) ir vyresnių (19-32 m.) - tai sutapo su jauniu - suaugusiu amžiaus intervalais. Apskaičiuotas Stjudento t (Student $t$ ) kriterijus parodè, kad vyresni regbininkai save vertina geriau nei jaunesni $(\mathrm{t}=-2,00 ; \mathrm{p}=0,048)$. Atsižvelgdami i šiuos skirtumus savęs vertinimo ir agresyvumo formų sąsajas analizuosime amžiaus grupèse atskirai.

Rezultatai parode, kad suminis agresyvumo ivvertis jaunesnių ir vyresnių regbininkų nesiskiria (Stjudento $\mathrm{t}=0,175 ; \mathrm{p}=0,861$ ). Atlikus atskiru agresyvumo formų analizę Man-Witney kriterijumi (1 pav.) nustatyta, kad vyresnių regbininkų labiau išreikštas negatyvizmas $(U=937,0 ; p=0,006)$, jaunesnių — itarumas $(U=951,5 ; \mathrm{p}=0,008)$ ir kaltès jausmas $(U=981,0 ; p=0,015)$. Kitu agresyvumo formu — tiesioginio agresyvumo, priešiškumo, susierzinimo, fizinès, netiesioginès, verbalinès agresijos bei nuoskaudos - rodikliai jaunesnių ir vyresnių regbininkų grupėse nesiskiria.

Analizuodami savęs vertinimo ryši su bendru agresyvumo rodikliu rèmèmés Pirsono (Pearson) koreliacijos koeficientu, nes skirstiniai statistiškai patikimai nesiskiria nuo normaliojo skirstinio. Vyresnių regbininku grupeje savęs vertinimo ir suminio agresyvumo rodiklio sąsajų neaptikta $(p>0,05)$. Jaunesnių regbininkų grupeje nustatyta neigiama koreliacija: žemesnis savęs vertinimas susijęs su aukštesniu agresyvumo įverčiu $(r=$ $-0,323 ; \mathrm{p}=0,021)$.

Analizuodami atskiras agresyvumo formas rèmėmès taip pat Pirsono koreliacijos koeficientu, kai skirstiniai statistiškai patikimai nesiskyrè nuo normaliojo skirstinio. Kai skirstiniai nebuvo pasiskirstę normaliuoju dèsniu naudojome neparametrini kriteriju — Spirmeno (Spearman) $\rho$ koreliacijos koeficientą. Taigi vyresnių regbininku grupeje nustatytas tiesioginis savęs vertinimo ir
Pav. Regbininkų agresyvumo formų vidurkiai amžiaus grupèse

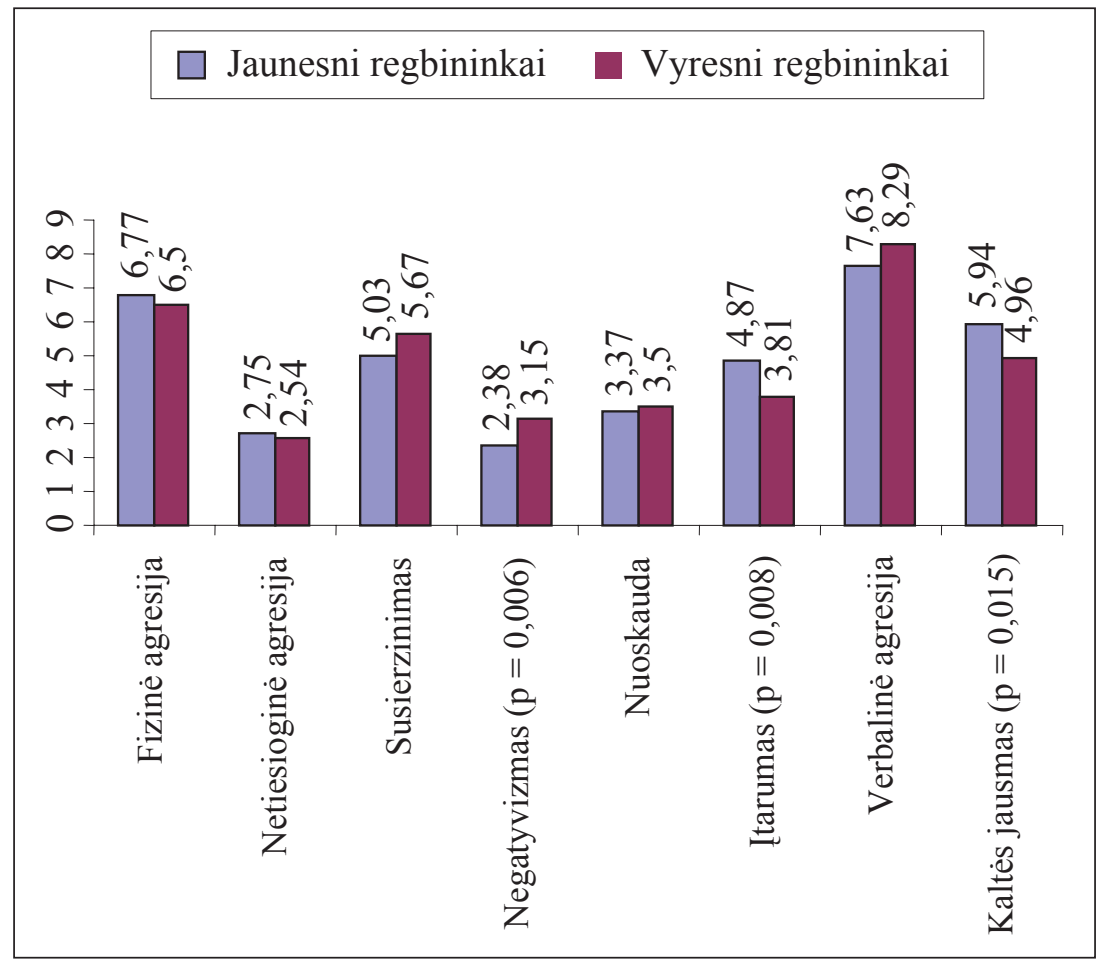

Lentelè. Jaunesnių regbininkų savęs vertinimo ir agresyvumo formų ryšys

\begin{tabular}{|l|c|c|c|c|}
\hline \multicolumn{1}{|c|}{$\begin{array}{c}\text { Agresyvumo } \\
\text { forma }\end{array}$} & Vidurkis & $\begin{array}{c}\text { Standartinis } \\
\text { nuokrypis }\end{array}$ & $\begin{array}{c}\text { Koreliacijos } \\
\text { koeficiento reikšmé }\end{array}$ & p reikšmé \\
\hline Priešiškumas & 10,077 & 2,88 & $-0,325$ (Pirsono) & 0,02 \\
\hline Susierzinimas & 5,039 & 2,33 & $-0,38$ (Pirsono) & 0,006 \\
\hline Negatyvizmas & 2,384 & 1,24 & $-0,325$ (Spirmeno $\rho)$ & 0,02 \\
\hline Nuoskauda & 4,558 & 1,64 & $-0,436$ (Spirmeno $\rho)$ & 0,001 \\
\hline
\end{tabular}


verbalinès agresijos ryšys $(p=0,366 ; p=0,008)$, jaunesnių regbininku grupeje nustatyta neigiama koreliacija tarp savęs vertinimo ir priešiškumo $(\mathrm{r}=-0,325 ; \mathrm{p}=0,020)$, susierzinimo $(\mathrm{r}=$ $-0,380 ; \mathrm{p}=0,006)$, negatyvizmo $(\mathrm{p}=-0,325$; $\mathrm{p}=0,020)$ ir nuoskaudos $(\mathrm{p}=-0,436 ; \mathrm{p}=0,001)$ (žr. lent.).

\section{REZULTATUQ APTARIMAS}

Rezultatai parodè, kad jaunesnių regbininkų savęs vertinimas žemesnis nei vyresnių, tačiau šio skirtumo negalima sieti vien su sportu. Tikètina, kad sportiné veikla palankiai veikia savęs vertinima, ypač kai išugdomi gebejjimai, sportiné karjera tęsiasi ilgai ir sėkmingai, bet tam tikras savęs vertinimo pakilimas po paauglystės, pasiekus jauno subrendusio žmogaus amžių, yra būdingas ir nesportuojantiems. Jaunesnių regbininkų -16 $18 \mathrm{~m}$. tiriamuju - savęs vertinimas dar nèra stabiliai susiformavęs, galbūt jaunesnių sportininku motyvas sportuoti yra susijęs su nepasitenkinimu savimi (Vainienè, Kardelis, 2008). Laukiant geru rezultatų iš sportininko, jo pasitikejjimas savimi aktyviai skatinamas treneriu ir komandos narių, o toks išorinis pastiprinimas labai svarbus teigiamam savęs vertinimui, socialumui (Šertvytienè, Laskienè, 2008).

Suminis agresyvumo ịvertis jaunesnių ir vyresnių regbininkų nesiskyrè, nors ir gauti savęs vertinimo skirtumai tarp amžiaus grupių. Tačiau atskiru agresyvumo formų palyginimas informatyvus (žr. pav.). Gautas reikšmingas skirtumas negatyvizmo, kaltès jausmo ir itarumo skalèse. Itarumas ir kaltès jausmas būdingesni jaunesniems regbininkams - jaunesni regbininkai labiau nepasitiki aplinkiniais ir projektuoja savo priešiškumą $\mathfrak{i}$ kitus. Kaltè ir gèda siejasi su numanomu arba realiu kitu žmonių nepalankiu vertinimu ir pasipriešinimu tokiam vertinimui, todèl jaunesni nepatyrę sportininkai jautresni kitu lūkesčiams, kritikai (Tangney, 1992). Negatyvizmas gali būti reiškiamas nuo pasyvaus pasipriešinimo iki konkrečių veiksmų prieš taisykles ar viršesnį žmogų. Tikètina, kad vyresni regbininkai labiau drịsta nepritarti kitu sugalvotoms taisyklëms ar garbingos kovos principams.

Duomenys parodè, kad tirtiems regbininkams būdingiausios verbalinès ir fizinès agresijos formos, t. y. aktyvus, atviras agresijos išreiškimas, o mažiausiai būdinga netiesioginè agresija ir negatyvizmas, t. y. „atsargesné“, pasyvesnè agresija. Tai atitinka kitų autorių išvadas, kad sportininkai linkę laisviau nei ne sportininkai reikšti agresiją (Malinauskas, 2003). Vyraujantis verbalinis išraiškos būdas (žr. pav.) rodo, kad dominuoja socialiai adaptyvus reagavimas. Deja, antroje vietoje - fizinè agresijos išraiška, kuri nèra adaptyvi.

Vyresnių regbininkų grupejje (aukštesnio savęs vertinimo) savęs vertinimo ir suminio agresyvumo rodiklio sąsajų neaptikta, tačiau jaunesnių regbininkų grupejje nustatytas neigiamas ryšys: kuo žemesnis savęs vertinimas, tuo aukštesnis agresyvumo ivvertis. Tokie rezultatai atitinka daugumos tyrèjų išvadas, kad būtent žemas savęs vertinimas yra agresyvumo rizikos veiksnys (Heimpel et al., 2002; Hubbard, 2006).

Vyresnių regbininku savęs vertinimas patikimai siejosi tik su verbaline agresija: kuo aukštesnis savęs vertinimas, tuo labiau išreikštas polinkis verbalinei agresijai. Kalbos vartojimas emociju išraiškai evoliucijos ir psichologijos požiūriu yra pažangus. Taigi aukštesnio savęs vertinimo 19$32 \mathrm{~m}$. regbininku agresyvumo išraiškas galima laikyti adaptyviomis. Pernelyg aukštas savęs vertinimas, perdètas teisumo jausmas tyrèjų siejamas su neadaptyviomis agresyvumo apraiškomis (Perez et al., 2005), tačiau nurodyti optimalaus geriausio savęs vertinimo ribas, kurioms esant agresyvumas dar adaptyvus, ne šio tyrimo tikslas.

Priešiškumas, susierzinimas, nuoskauda ir negatyvizmas neigiamai koreliuoja su jaunesniu (16-18 m.) regbininkų savęs vertinimu. Dèsninga, kad žemas savęs vertinimas labiau nei aukštas pažeidžiamas kritikos, izžeidimo, lengvai kyla gynybinès agresijos reakcijos (Perez et al., 2005). Galima teigti, kad jaunesni žemo savęs vertinimo regbininkai turi polinkị reaguoti gana pasyviu pasipriešinimu ir demonstruoti priešišką elgesî, nukreiptą i viršesnius žmones. Grèsmé savigarbai, pavyzdžiui, ižeidimas, kritika, provokuoja priešiškumą kaip atsakomaji veiksmą, kuris leidžia susigrąžinti jautrų pažeidimui žemą savęs vertinimą.

Sportininkų agresyvumas susijęs ne tik su ivairiais situaciniais veiksniais, bet ir su asmeninèmis savybėmis. Mūsu tyrimo rezultatai parodè, kad savęs vertinimas nevienareikšmiškai susijęs su i̇vairiomis agresyvumo formomis. Tolesnè ivairių asmenybès ypatumu ir agresyvumo apraiškų analizè būtų prasminga siekiant kuo veiksmingiau išnaudoti sportininkų agresijos energija, prognozuoti situacijas, kuriomis agresyvumas reiškiamas neadaptyviai (sabotažo, taisykliu pažeidimo ar pan.). 


\section{IŠVADOS}

Regbininkams būdingiausios aktyvios - fizinè ir verbalinè - agresijos formos. Jaunesniems regbininkams būdingesnis įtarumas ir kaltès jausmas, vyresniems — negatyvizmas.
Aukštesnis vyresnių regbininkų savęs vertinimas susijęs su labiau išreikšta verbaline agresija.

Jaunesnių regbininkų žemesnis savęs vertinimas siejasi su labiau išreikštu bendru agresyvumu ir labiau išreikštomis atskiromis agresyvumo formomis: priešiškumu, susierzinimu, nuoskauda bei negatyvizmu.

\section{LITERATŪRA}

Brandenburg M., A., Butterwick, D. J., Hiemstra, L. A., Nebergall, R., Laird, J. (2007). A comparison of injury rates in organised sports, with special emphasis on American bull riding. International Journal of Sports Medicine, 8 (2), 78-86.

Bushman, B. J., Baumeister, R. F. (1998). Threatened egotism, narcissism, self-esteem, and direct and displaced aggression: Does self-love or self-hate lead to violence? Journal of Personality and Social Psychology, 75 (1), 219-229.

Dumčienė, A., Sipavičienė, S., Šukys, S. (2008). Mokiniu sportavimo sąsajos su psichosocialine sveikata. Sveikatos mokslai, 3, 1693-1696.

Endresen, I. M., Olweus, D. (2005). Participation in power sports and antisocial involvement in preadolescent and adolescent boys. Journal of Child Psychology \& Psychiatry, 46 (5), 468-478.

Fields, S. K., Collins, Ch. L., Comstock, R. D. (2007). Conflict on the courts. A review of sports-related violence literature. Trauma, Violence \& Abuse, 8 (4), 359-369.

Findlay, L. C., Coplan, R. J. (2008). Come out and play: Shyness in childhood and the benefits of organized sports participation. Canadian Journal of Behavioural Science, 40 (3), 153-161.

Heimpel, S., Wood, J. V., Marshall, M. A., Brown, J. D. (2002). Do people with low self-esteem really want to feel better? Self-esteem differences in motivation to repair negative moods. Journal of Personality and Social Psychology, 82 (1), 128-147.

Hubbard, D. H. (2006). Should we be targeting self-esteem in treatment for offenders: Do gender and race matter in whether self-esteem matters? Journal of Offender Rehabilitation, 44 (1), 39-57.

Kirkpatrick, L. A., Waugh, Ch. E., Valencia, A., Webster, G. D. (2002). The functional domain specificity of self-esteem and the differential prediction of aggression. Journal of Personality and Social Psychology, 82 (5), $756-767$.

Malinauskas, R. (2003). Sporto psichologijos pagrindai: studiju knyga. Kaunas: LKKA.
Perez, M., Vohs, K. D., Joiner, T. E. (2005). Discrepancies between self - and other - esteem as correlates of aggression. Journal of Social and Clinical Psychology, 24 (5), 607-620.

Ruibytė, L. (2004). Situacinių veiksnių itaka sportininkų agresyvaus elgesio poreiškiui. Ugdymas. Küno kultūra. Sportas, 4 (54), 79-84.

Storch, E. A., Bagner, D. M., Bongilatti, S., Werner, N. R., Storch, J. B. (2005). Psychosocial correlates of overt aggression in intercollegiate athletes. Counseling \& Clinical Psychology Journal, 2 (1), 68-74.

Stornes, T., Roland, E. (2004). Handball and aggression: An investigation of adolescent handball players' perceptions of aggressive behavior. European Journal of Sport Science, 4 (1), 1-13.

Šertvytienė, D., Laskienė, S. (2008). Sportuojančių paaugliu vertybinès orientacijos kaip socialinès kompetencijos veiksnys. Ugdymas. Küno kultūra. Sportas, 4 (71), 104-110.

Šniras, Š., Dumčienė, A., Dumbliauskas, A. (2007). Sportuojančiu ir nesportuojančiu mokinių socialinių igūdžių ypatumai. Pedagogika, 85, 110-115.

Tangney, J. P., Wagner, P., Fletcher, C., Gramzow, R. (1992). Shamed into anger? The relation of shame and guilt to anger and self-reported aggression. Journal of Personality and Social Psychology, 62 (4), 669-675.

Vainienè, E., Kardelis, K. (2008). Jaunimo mokyklų moksleivių fizinio aktyvumo sąsajos su mokymosi motyvacija, savigarba ir socialine integracija. Ugdymas. Küno kultūra. Sportas, 1 (68), 100-107.

Valickas, G. (1997). Psichologinès asocialaus elgesio ištakos. Vilnius: Lietuvos teisès akademija.

Žukauskienè, R. (2006). Kriminalinio elgesio psichologija. Vilnius: Mykolo Riomerio universitetas.

Ратанова, Т. А., Шляхта, Н. Ф. (2008). Психодиагностические методы изучения личности. Москва: Флинт. C. $71-78$. 


\title{
RELATIONS BETWEEN RUGBY PLAYERS' SELF-ESTEEM AND FORMS OF AGGRESSION
}

\author{
Loreta Zajančkauskaitė-Staskevičienė, Asta Milerytė \\ Vytautas Magnus Uuniversity, Kaunas, Lithuania
}

\begin{abstract}
The aggressive behavior during the sport fight and also not becomes a serious social problem. Many authors seek to find out what determines appearance of intolerant aggressive behavior. Researches analyse situational factors, personal traits and context. There are close links between self-esteem and aggressive reactions, ability to control aggressive impulses or to work off one's energy in socially acceptable way. There is not much research on self-esteem in the context of sports activities, for this reason the object of this work was the sportsperson's sport self-esteem and forms of aggression in contacts. According to statistics of players' injuries during rugby competition, rugby is attributing to aggressive sport, for this reason we expected that rugby players' forms of aggression would be clear by expressed. The aim of this research was to establish relation between rugby players' self-esteem and forms of aggression.

The subjects were 104 male rugby players training in junior and adult teams. Participants were between 16 and 32 years old. Their mean age was 20.75 years. We used Rosenberg (1986) Self-esteem Scale and BussDurkee (1957) Aggression Questionnaire. SPSS program (10.1 version) was used for data processing.

Results showed that verbal and physical aggression forms were most typical of rugby players, i. e. their active and open aggression.

The data analysis showed that the sense of guilt was more typical of younger rugby players - they more distrusted other people and more tended to show their hostility to others. Negativism was more typical of older rugby players. We conclude that older rugby players were braver to oppose other people or fair play principles.

There was no connection between self-esteem and total aggression index in older rugby players' who demonstrated higher self-esteem. Howewer, there was negative connection in younger rugby players' group: the lower self-esteem, the higher aggression. These results confirmed that low self-esteem was a risk factor for aggression. Older rugby players' self-esteem was linked to verbal aggression. Hostility, irritation, mortification and negativism were adversely by connected with younger rugby players' self-esteem.
\end{abstract}

Keywords: aggression, instrumental aggression, self-esteem.

Gauta 2008 m. gruodžio 17 d.

Received on December 17, 2008

Priimta 2010 m. gegužès $31 \mathrm{~d}$.

Accepted on May 31, 2010

Loreta Zajančkauskaitè-Staskevičienė

Vytauto Didžiojo universitetas

(Vytautas Magnus University)

Laisvès al. 53-506, LT-44309 Kaunas

Lietuva (Lithuania)

Tel 837327825

E-mail1.zajanckauskaite@smf.vdu.1t 